Е. Е. Малохвій, В. С. Бугай, Г. І. Молчанов, О. П. Черних

Національний технічний університет «Харківський політехнічний інститут», Харків, Україна

\title{
АНАЛІТИЧНИЙ ОГЛЯД ТА ПОРІВНЯННЯ СУЧАСНИХ JAVASCRIPT РIШЕНЬ ДЛЯ РОЗРОБКИ ВЕБ-ДОДАТКІВ
}

\begin{abstract}
Ан отац і я. Предметом дослідження в статті є сучасні JavaScript рішення для розробки веб-додатків, a caме JavaScript бібліотека React та фреймворк Vue. Мета роботи - аналітичний огляд та порівняння сучасних JavaScript piшень для розробки веб-додатків виходячи з трендів на 2021 рік. Для достовірності дослідження поточного стану ринку було використано наступні інструменти: Google Trends, Stack Overflow Developer Survey, GitHub Stars, The State of JavaScript, найпопулярніші платформи пошуку роботи для розробників. В статті наведено порівняння популярних: бібліотеки React та фреймворку Vue, відзначено їх переваги і недоліки.
\end{abstract}

Ключов і слов а : JavaScript, React, Vue, веб-додаток, фреймворк, бібліотека.

\section{Вступ}

Коли тільки з'явився Інтернет та статистичні сайти, ніхто не замислювався про оптимізацію швидкості завантаження та масштабування веб-додатків. На той час цілі та завдання, що стоять перед розробниками, дуже відрізнялися від сьогоденних. Але з розвитком веб-технологій та поширення інтернету 3'явилася потреба в бібліотеках та фреймворках, які здатні надати розробникам: високу швидкість, гнучкість, простоту та масштабованість. Досить швидко число бібліотек та фреймворків, націлених на вирішення цих завдань, почало зростати. Отже, JavaScript-бібліотеки стали невід'ємною частиною кожного сучасного веб-додатку. Існує безліч подібних бібліотек та фреймворків, в результаті розробникам постійно доводиться ставити питання про те, що вибрати. В даній статті не буде розглянути усі існуючі бібліотеки та фреймворки, зупинимося конкретно на двох, а саме: React та Vue.

Основною метою статті $\epsilon$ рекомендації до вибору технології для вивчення у 2021 році. Це актуальне питання як для програмістів-початківців, так і для більш досвідчених, які думають про те, щоб переключитися на щось нове. Автори статті намагалися бути максимально об'єктивними, саме тому як докази використовували статистичні дані про нинішню ситуацію на ринку.

У статті наведено порівняння популярних: бібліотеки React та фреймворку Vue, відзначено їх переваги і недоліки, а також наведено трохи особистої думки авторів, які, звичайно, суб'єктивні, але не упереджені та базуються на досвіді авторів у використанні обох фреймворків.

\section{Виклад основного матеріалу}

Почнемо з історії та передумови виникнення React та Vue. React - JavaScript-бібліотека з відкритим вихідним кодом [1], створена Джорданом Валке 3 Facebook. Перед компанією стояло завдання покращити процеси створення та рендерингу інтерфейсів, адже Facebook необхідно було розробляти та підтримувати. Вже на той момент це був величезний проект, а існуючих технологій не вистачало. Вперше React використовувався в стрічці новин Facebook в 2011 році і пізніше в стрічці Instagram в 2012-му. Але лише у 2013 році спільноті розробників на конференції JSConf US було представлено вихідний код. Пройшло вже багато часу, вийшли сотні апдейтів, фіксів та доповнень функціоналу, але з тих пір React залишається найпопулярнішим серед 3 гігантів. На сьогодні версія 17.0.2 від 27 жовтня 2021 року є найактуальнішою. За рахунок своєї популярності та зручності багато великих компаній використовують цю бібліотеку для розробки своїх продуктів. Серед них Facebook, Netflix, Yandex та багато інших.

Vue.js - JavaScript-фреймворк [2], створений у 2014 році Еваном Ю, колишнім співробітником Google, хоча розробку він починав ще у стінах компанії. Факт того, що повноцінний фреймворк був створений одним програмістом - одна 3 головних відмінностей Vue, адже за рештою стоять технічні гіганти. На початковому етапі Еван повністю займався написанням коду, оновленням документації, виправленням багів та просуванням свого дітища. 3 моменту появи Vue минуло 7 років і вже зараз він зрівнявся за популярністю 3 Angular від такого гіганта, як Google. Найсвіжіший реліз Vue 2.6.14 був представлений 7 червня 2021 року. А також 18 вересня 2020 була показана версія 3.0, яка вже незабаром стане основною [3]. Змішення можливостей інших успішних JavaScript-фреймворків, одна 3 найкращих документацій (найкраща китайською) та легкість початку роботи робить його таким популярним. Серед великих компаній, які використовують всі переваги Vue, відзначимо Zoom, GitLab, Behance, Font Awesome.

У світі JavaScript нові фреймворки та бібліотеки 3'являються чи не щодня. Насправді, це майже безперервний процес, під час якого лідери змінюються практично кожні кілька місяців. Щороку з'являються нові «вбивці», які обіцяють більш високу продуктивність, зручніше використання та меншу кількість багів. Цей процес не можна зупинити, за ним залишається стежити, щоб не опинитися в ситуації, коли твої навички будуть застарілими. Для відстеження трендів існує багато інструментів.

Важливо пам'ятати, що з повноти картини необхідно звертатися до кількох із них. Давайте розглянемо поточний стан ринку.

Google Trends - статистика пошукових запитів досить точно показує інтерес розробників до різних технологій [4]. 
Розглянемо статистику пошукових запитів за останні 12 місяців у світі (рис. 1). Проаналізувавши ix, стає очевидним, що React впевнено утримував лідерську позицію, але згодом почав втрачати. Кількість пошукових запитів у світі по Vue за останній рік зрівнялася з показниками React. Особливо Vue додав під кінець року, на думку авторів це пов'язано з появою альфа версії Vue 3.0 в загальному доступі та продовженням підтримки командою розробників Vue попередньої версії.

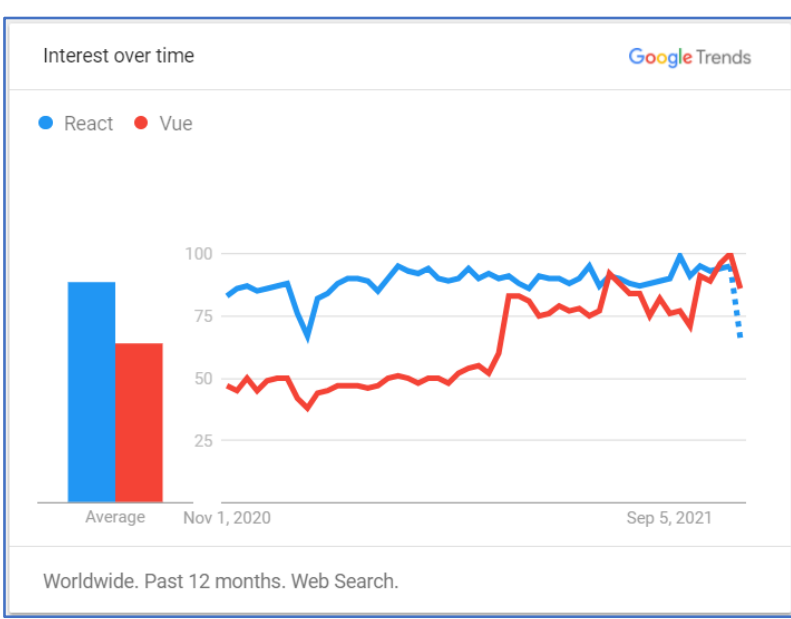

Рис. 1. Статистика пошукових запитів в Google (Світова)

Але все ж світова статистика не дає нам право однозначно відсунути React на задній план. а графіку (рис. 2) наведено статистику пошукових запитів за останні 12 місяців на території України (з урахуванням АР Крим). Статистика невтішна для Vue. Проаналізувавши графік, робимо висновок, що українські розробники більше роблять свій вибір убік React ніж Vue.

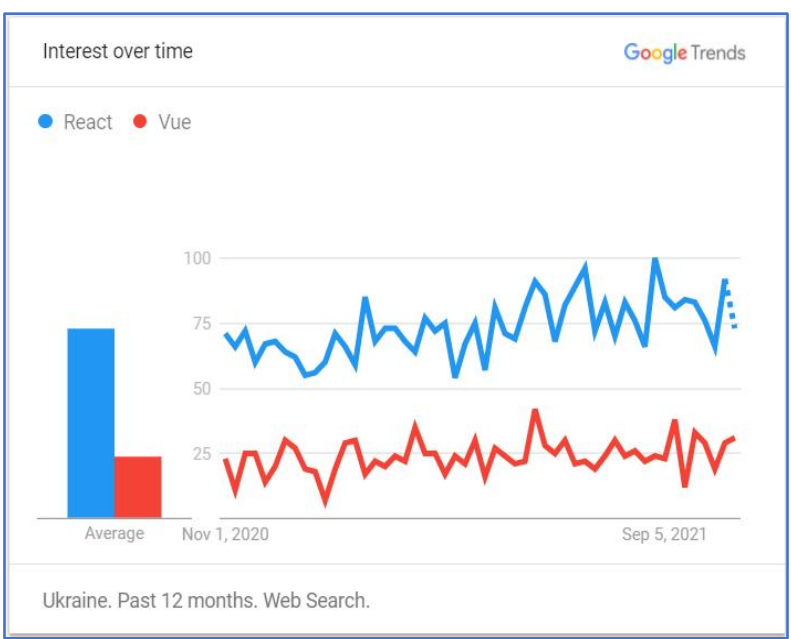

Рис. 2. Статистика пошукових запитів в Google (Україна)

Stack Overflow Developer Survey - щороку найпопулярніший форум програмістів проводить власне дослідження, в якому можуть взяти участь усі охочі [5]. Якщо звернути увагу на результати опитування 2020 року на тему улюбленого веб-фреймворку або бібліотеки (рис. 3), розрив між React i Vue.js становить трохи менше 3\%. Тепер ситуація не виглядає такою однозначною, як після перших двох графіків.

GitHub Stars - за кількістю зірок у репозиторію можна 3 легкістю сказати про популярність чогось серед розробників. На даний момент у React - 177 тисяч зірок, у той час як у Vue.js - 190 тисяч. Якщо дивитися тільки на ці дані (рис. 4), то Vue явно лідирує, а отже, немає сенсу витрачати час на React.

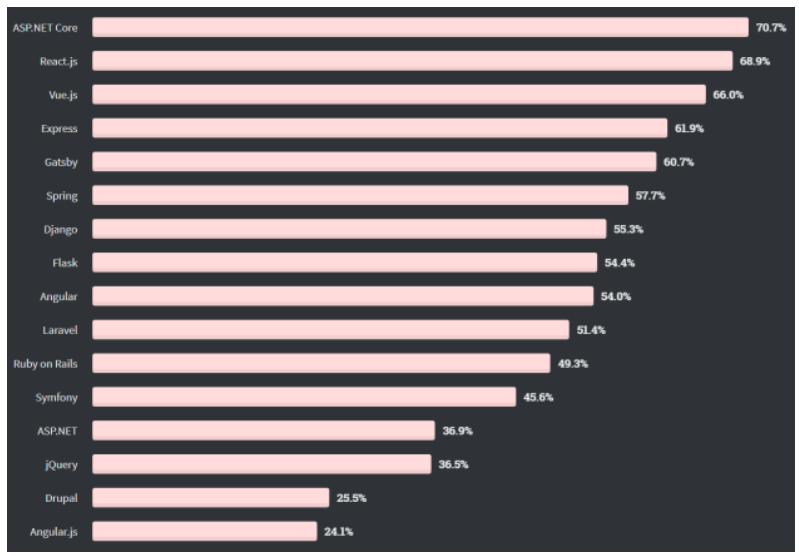

Рис. 3. Відсоток розробників, які розробляють мовою або технологією і виявили зацікавленість у продовженні розвитку з нею

Але, як вже було згадано вище, необхідно завжди звертатися до кількох ресурсів, щоб отримати повну картину.

The State of JavaScript - опитування, присвячене виключно JavaScript.

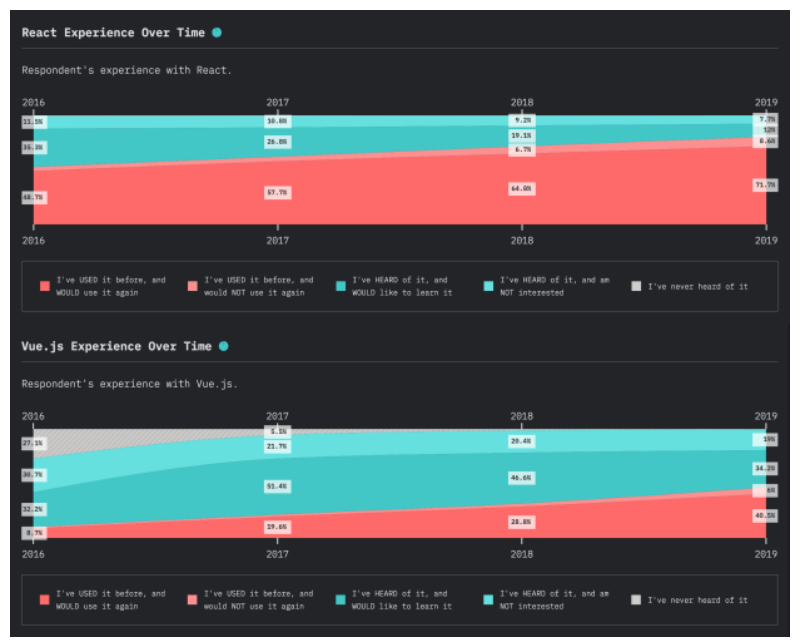

Рис. 4. Порівняння досвіду розробників під час використання певної технології

Де, як не тут, можна виявити справжнє ставлення розробників до інструментів, що використовуються.

3 цих графіків (рис. 4) можна зробити висновок про більшу кількість людей, які використовують React [6]. Але водночас відсоток тих, хто спробував i вирішив більше не застосовувати Vue.js, - нижче [7].

Кількість вакансій - мабуть, найважливіший показник. Якщо всі попередні графіки представляли 
безпосередньо думку розробників, ці дані відображають потреби бізнесу. Чим більше опублікованих оголошень, тим більше шансів отримати роботу за менший час.

Було проаналізовано найбільш популярні платформи пошуку роботи для розробників.

Станом на сьогодні, бізнес більше надає перевагу React ніж Vue. Як видно із графіка (рис. 5), React не залишає жодних шансів Vue.

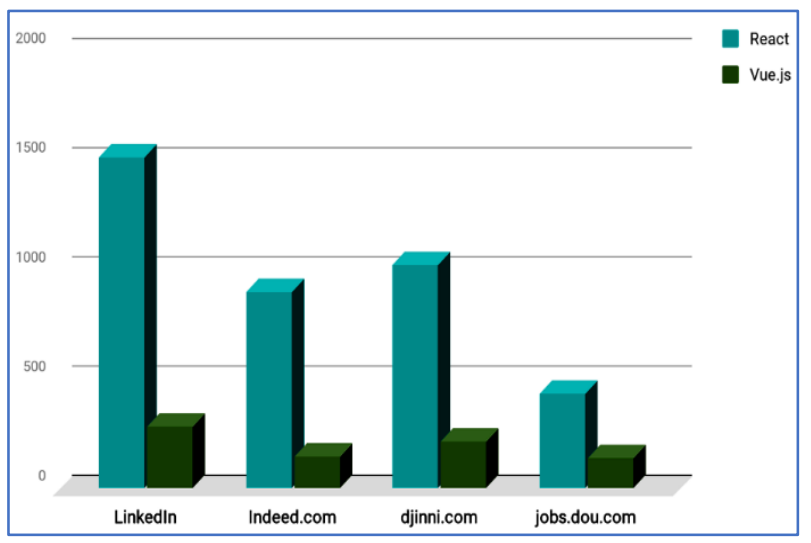

Рис. 5. Кількість вакансій на найбільш популярних платформах пошуку роботи для розробників

Зміни в інтерфейсі будь-якого веб-додатку виконуються шляхом модифікації об'єктної моделі документа (DOM). Існують такі поняття, як віртуальна DOM та реальна DOM. Від того, як організований процес роботи з DOM, серйозно залежить продуктивність JavaScript рішення для розробки веб-додатків. У React використовується віртуальна DOM - це легковажна система, яка не залежить від браузера. Однією з основних причин популярності React $€$ те, що бібліотека дуже ефективно працює з DOM [8]. У Vue також використовується віртуальна DOM, але, в порівнянні 3 React, Vue відрізняється більш високою продуктивністю та стабільністю [9].

Спільноти, що складаються навколо технологій, серйозно впливають на їх розвиток та розповсюдження. Зокрема, члени спільнот здатні допомогти основним розробникам технологій, вони створюють різні додатки, а також допомагають новачкам. Підтримкою та розвитком самої бібліотеки React займається Facebook. Це дає тому, хто обирає цю бібліотеку як основу свого веб-додатку, досить високий рівень впевненості в тому, що React у найближчому майбутньому не перетвориться на якийсь занедбаний усіма проект.

Співтовариство React-розробників створило та підтримує безліч додаткових інструментів. На відміну від React, Vue - це проект, біля витоків якого стоїть звичайна людина, а не велика корпорація. Як результат - спочатку після появи цей фреймворк виглядав в очах розробників не особливо надійним. Однак через деякий час Vue став надзвичайно популярним, в його розвиток робить внесок безліч розробників. Фактично, можна говорити про те, що саме спільнота Vue-розробників це та сила, яка підтримує проект.
Якщо розглядати питання розміру дуже спрощено, можна сказати, що React трохи більший, ніж Vue. Розмір React - близько 100 Кб, розмір Vue - близько 80 Кб. Розмір JavaScript бібліотеки або фреймворку - це дуже важливий показник, який дуже впливає на продуктивність веб-додатків. Чим він менший, тим краще.

Однак тут слід зазначити, що React, для реалізації певних можливостей, потребує сторонніх бібліотек. Однією з таких можливостей є маршрутизація. Vue ж - це проект, що володіє більшим переліком стандартних можливостей, хоча і при роботі з Vue без додатків теж не обійтися. I React i Vue, все ж таки, мають досить скромні розміри, що робить їх цілком придатними для розробки невеликих за розміром веб-додатків.

Перш ніж обирати технологію для чергового проекту, програмісти та управлінці зазвичай цікавляться тим, у яких існуючих проектах ця технологія вже застосовується.

Якщо говорити про те, на чому засновані React $\mathrm{i}$ Vue, про JavaScript та інші веб-технології, можна сказати, що все це застосовується в незліченній кількості компаній.

Якщо ж подивитися на конкретні приклади застосування React тa Vue, то можна виділити, наприклад, такі компанії для застосування React:

- Facebook - як уже було сказано, ця компанія створила та підтримує React, i, крім того, активно використовує цю бібліотеку;

- Twitter - платформа, орієнтована на публікацію коротких повідомлень;

- Instagram - на цій платформі акцент робиться на публікацію зображень;

- WhatsApp - популярний месенджер.

Приклади застосування Vue:

- GitLab - проект, який допомагає розробникам спільно створювати різноманітні додатки;

- 9Gag - проект, відомий мемами та іншими подібними матеріалами;

- Nintendo - розробник ігор;

- Grammarly - сервіс з перевірки граматики.

Стосовно гнучкості рішень наведених у статті, Ядро React надає лише базовий функціонал. Під час комерційного використання цієї бібліотеки ії можливості доводиться розширювати. Це дає розробнику величезний рівень гнучкості щодо вибору додаткових інструментів.

Існують засоби для розробки інтерфейсів, ідеї, закладені в які можна вважати прямо протилежними тим, які закладені в React. Наприклад - це Angular фреймворк, до складу якого включено безліч стандартних засобів. Плюс цього готовий набір інструментів, які добре поєднуються один з одним. Мінус - відсутність рівня гнучкості у виборі додатків, який дає React.

Якщо говорити про конкретні завдання, які вирішуються за допомогою додаткових бібліотек, що використовуються з React, то тут можна відзначити, наприклад, маршрутизацію, керування станом додатків, серверний рендеринг, розробку додатків для мобільних 
пристроїв. Vue, на відміну від React, дає розробнику більший набір стандартних інструментів [10], які дозволяють вирішувати ті самі завдання, які у екосистемі React зазвичай вирішують $з$ допомогою сторонніх бібліотек.

I на останок розглянемо «криву здатності навчатися» для React та Vue. Для початку дамо загальне визначення цього терміну. Це графічне представлення зміни швидкості опанування певного знання або виду діяльності.

У нашому випадку йдеться про швидкість освоєння React та Vue. Проаналізувавши результати опитування The State of JavaScript [11] робимо висновки, що Vue освоїти легше, ніж React. Як видно з результатів опитування, багато хто з розробників які користувалися React, планують знову користуватися цією бібліотекою. Чимало розробників зацікавлені у вивченні React. Якщо ж говорити про Vue, то можна відзначити, що показник використання цього фреймворку не такий великий, як у React, а показник, що вказує на зацікавленість у вивченні, перевищує React. Це дозволяє говорити про те, що Vue - це фреймворк, який дуже багато хто хоче спробувати. В результаті, враховуючи те, що Vue легше в освоєнні, очікується, що в майбутньому зросте кількість тих, хто використовував Vue i планує використовувати знову.

\section{Висновок}

У статті розглянути фреймворки React та Vue. Обидва мають свої переваги та недоліки, чимось вони схожі, а чимось різняться. React набагато популярніший, а отже спеціаліст який володіє цим фреймворком $є$ більш цікавим з точки зору роботодавця у порівнянні з Vue. Але насамперед, Vue легше в вивченні як новачкам, так і тим, хто вже має досвід роботи з будь-яким із фреймворків.

Отже, популярність Vue зростає, насамперед завдяки чудовій документації, простоті використання та можливостям поступового впровадження. Vue розробляється та підтримується командою, має ширший набір вбудованих інструментів та рішень. Що стосується швидкості розробки, за допомогою Vue CLI 4 потрібно лише кілька тижнів, щоб налаштувати та випустити продукт, готовий до продажу.

Якщо зібрати воєдино все те, що перераховано в статті, можна зробити такі висновки:

- React популярніший за Vue;

- React користується підтримкою великої компанії, тоді як Vue такої підтримки немає;

- Vue краще підійде, якщо необхідно негайно розпочати розробку;

- Vue дає змогу отримати доступ до більшої кількості інструментів від розробників фреймворку та їх підтримку;

- в Vue простежується змішання можливостей деяких інших успішних фреймворків у тому числі React. Що дає змогу використовувати найкращі парадигми та підходи до розробки веб-додатків на сьогоднішній день в одному фреймворку;

- розмір Vue менший за розмір React.

\section{СПИСОК ЛІТЕРАТУРИ}

1. Documentation for React - Режим доступу: https://reactjs.org/docs/getting-started.html

2. Documentation for Vue.js 2.x - Режим доступу: https://vuejs.org/v2/guide/

3. Documentation for Vue.js 3.x - Режим доступу: https://v3.vuejs.org/guide/

4. Google Trends. Comparison of React and Vue - Режим доступу: https://trends.google.com/trends/explore?q=React,Vue

5. Stack Overflow Developer Survey 2020 - Режим доступу: https://insights.stackoverflow.com/survey/2020\#technology-mostloved-dreaded-and-wanted-web-frameworks-loved 2

6. The State of JavaScript. React Experience Over Time - Режим доступу: https://2019.stateofjs.com/front-end-frameworks/react/

7. The State of JavaScript. Vue Experience Over Time - Режим доступу: https://2019.stateofjs.com/front-end-frameworks/vuejs/

8. React Cookbook: Recipes for Mastering the React Framework 1st edition / David Griffiths, Dawn Griffiths - O'Reilly Media, 2021.

9. Front-End Development Projects with Vue.js: Learn to build scalable web applications and dynamic user interfaces with Vue 2 / Raymond Camden, Hugo Di Francesco, Clifford Gurney, Philip Kirkbride, Maya Shavin - Packt Publishing, 2020.

10. Vue.js 3 Cookbook: Discover actionable solutions for building modern web apps with the latest Vue features and TypeScript 1st edition / Heitor Ramon Ribeiro - Packt Publishing, 2020.

11. The State of JavaScript. Front-end Frameworks Overview - Режим доступу: https://2019.stateofjs.com/front-endframeworks/\#front_end_frameworks_section_overview

Received (Надійшла) 15.10.2021

Accepted for publication (Прийнята до друку) 17.11.2021

\section{Analytical overview and comparison of modern JavaScript solutions for web application development \\ E. Malokhvii, V. Buhai, H. Molchanov, O. Chernykh}

Abstract. The subject of research in the article is modern JavaScript solutions for web application development. The purpose of the work is to provide an analytical review of JavaScript solutions for web application development. Moreover, a comparison in the article is based on trends for 2021. For the reliability of research of the current state of the market, authors used the following tools: Google Trends, Stack Overflow Developer Survey, GitHub Stars, State of JavaScript, the most popular job search platforms for developers. The article compares the well-known React library and the young Vue framework, highlighting their advantages and disadvantages.

Keywords : JavaScript, React, Vue, web application, framework, library 